\title{
Fabrication of CdS/SnS Heterojunction for Photovoltaic Application
}

\author{
Hongnan Li, Shuying Cheng*, Jie Zhang*, Weihui Huang, Haifang Zhou, Hongjie Jia \\ Institute of Micro-Nano Devices \& Solar Cells, School of Physics and Information Engineering, Fuzhou \\ University, Fuzhou, China \\ Email: sycheng@fzu.edu.cn, ${ }^{*}$ zhangjie fj@139.com
}

Received 28 December 2014; accepted 18 January 2015; published 21 January 2015

Copyright (C) 2015 by authors and Scientific Research Publishing Inc.

This work is licensed under the Creative Commons Attribution International License (CC BY).

http://creativecommons.org/licenses/by/4.0/

(c) (i) Open Access

\begin{abstract}
SnS/CdS heterojunction is a promising system for photovoltaic application. SnS thin films were thermally evaporated onto CdS/ITO coated glass substrates. The structure of the device was glass/ ITO/CdS/SnS/In/Ag and I-V curves of the fabricated devices were measured under dark and illuminated conditions, respectively. We discussed the relationship of the thickness and annealing temperature of CdS buffer layers with the performance of SnS/CdS heterojunctions. The optimum thickness and annealing temperature of the $\mathrm{CdS}$ buffer layers were $50 \mathrm{~nm}$ and $350^{\circ} \mathrm{C}$, respectively. The best device had a conversion efficiency of $0.0025 \%$.
\end{abstract}

\section{Keywords}

SnS Films, Heterojunction, Thermally Vacuum-Evaporation, I-V Curves

\section{Introduction}

Tin monosulfide (SnS) is one of the most promising solar cell absorber materials because it has appropriate electrical and optical properties and the constituent elements are non-toxic and cost-effective. SnS usually exhibits p-type conductivity and it is reported to have a direct bandgap of about $1.3 \mathrm{eV}$ and an indirect bandgap of about $1.0 \mathrm{eV}$ [1] [2].

SnS thin films have been deposited by various methods such as thermal evaporation [3], spray pyrolysis [4], sulfurization [5], chemical bath deposition [6] and electrochemical deposition [7]. CdS is the most common material for window layer of a heterojunction solar cell. H. Noguchi reported that the efficiency of a SnS/CdS solar cell was $0.29 \%$ [8]. K. T. R. Reddy [4] improved the conversion efficiency to $1.3 \%$. ZnS/SnS [9], ZnO/SnS [10] and $\mathrm{SnS}_{2} / \mathrm{SnS}$ [11] heterojunction solar cells were also reported but their efficiency was even lower than that of

\footnotetext{
${ }^{*}$ Corresponding authors.
}

How to cite this paper: Li, H.N., Cheng, S.Y., Zhang, J., Huang, W.H., Zhou, H.F. and Jia, H.J. (2015) Fabrication of CdS/SnS Heterojunction for Photovoltaic Application. World Journal of Condensed Matter Physics, 5, 10-17.

http://dx.doi.org/10.4236/wjcmp.2015.51002 
$\mathrm{CdS} / \mathrm{SnS}$ heterojunction solar cells. The current efficiency of the SnS photovoltaic device is $2.46 \%$ [12], which is far less than the theoretical maximum efficiency of 32\% [13]. Further research is necessary to explore the reasons for the low performance, and improve the potential of SnS heterojunctions. In this work, we focused on the effects of thickness and annealing temperature of CdS buffer layers on the properties of SnS/CdS heterojunctions. The annealing conditions had much influence on the SnS phase constitution and electrical properties. The proper thickness of CdS buffer layer contributed to lower the reverse dark current and improve the open circuit voltage.

\section{Experimental}

ITO coated glass substrates were carefully cleaned in deionized water, acetone, ethanol and deionized water in sequence. For each step, the substrates were cleaned for $15 \mathrm{~min}$ in an ultrasonic bath. After a rinse with deionized water, the substrates were dried in a vacuum oven for $30 \mathrm{~min}$.

For CdS buffer layer deposition, $10 \mathrm{ml}$ of $0.002 \mathrm{M} \mathrm{CdCl}_{2}, 10 \mathrm{ml}$ of $0.02 \mathrm{M} \mathrm{NH}_{3} \mathrm{Cl}$ and $10 \mathrm{ml}$ of $0.01 \mathrm{M}$ $\left(\mathrm{NH}_{2}\right)_{2} \mathrm{CS}$ were prepared respectively in advance. Then the $\mathrm{CdCl}_{2}$ and $\mathrm{NH}_{3} \mathrm{Cl}$ solutions were mixed and diluted by $70 \mathrm{ml}$ deionized water. When the mixed solution was heated to $80^{\circ} \mathrm{C}$, the $\left(\mathrm{NH}_{2}\right)_{2} \mathrm{CS}$ solution was added into it and the $\mathrm{pH}$ value of the solution was adjusted to 11 by mixing ammonia. Finally, the CdS films were annealed at $350^{\circ} \mathrm{C}$ in vacuum for 2 hours.

SnS thin films were deposited on the CdS layers by evaporating SnS powder (with 99.6\% purity). The SnS source material was placed in the molybdenum boat and the substrate temperature was set at room temperature. The evaporation process was carried out in a vacuum coating unit at $10^{-3}$ Pa pressure with a deposition rate of 4 $\AA / s$. The thickness of the SnS films was about $1.5 \mu \mathrm{m}$. Indium and silver thin films were successively deposited onto the SnS layers by thermal evaporation as the back contact. The thicknesses of the indium and silver films were about $100 \mathrm{~nm}$ and $800 \mathrm{~nm}$ respectively. 8 solar cell samples were fabricated. The samples numbered 1-4 were with different CdS thicknesses, the ones numbered 5-8 were with different annealing temperatures. Figure 1 shows the section view of one sample.

A Philips X'Pert-MPD X-ray diffractometer (XRD) was used to identify the phases and structures of the SnS films. The optical transmittance and reflectance versus wavelength measurements were made using an Agilent CARY 5000 Scan UV-Vis-NIR spectrophotometer. Observations of the surface topology and topography of SnS films were carried out using a Philips XL 30 environmental scanning electron microscope (ESEM) with an energy dispersive X-ray (EDS) analysis attachment. The electrical resistivity and free carrier density were measured by a HMS 3000 Hall Effect Measurement System. The solar cell measurements were made using a simulated AM 1.5 spectrum set to $100 \mathrm{~mW} / \mathrm{cm}^{2}$ and the $\mathrm{J}-\mathrm{V}$ measurements were made using a Keithely 4200 source meter.

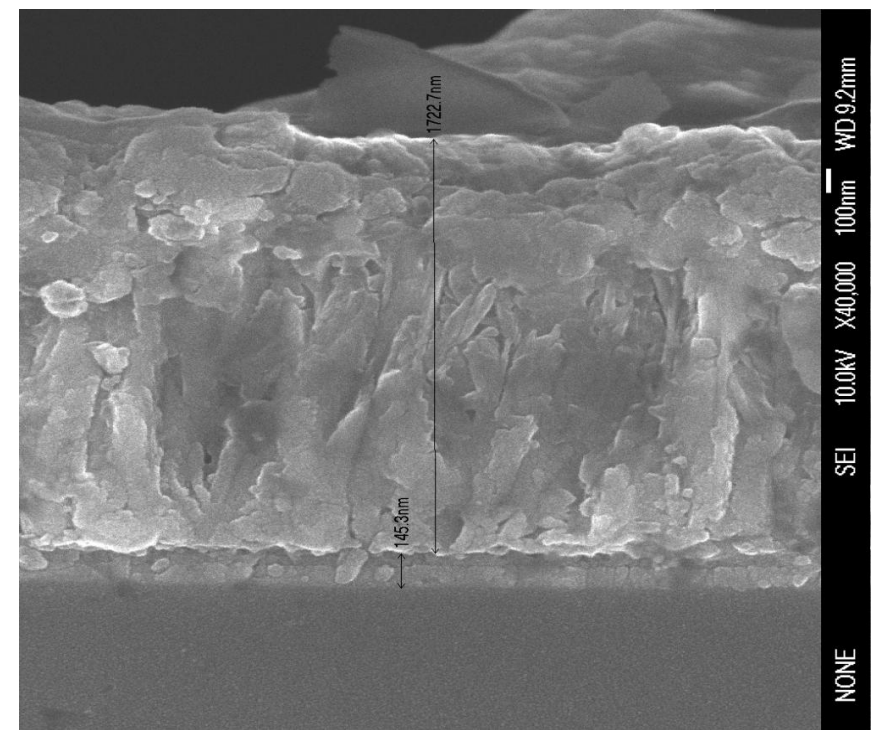

Figure 1. The section view of samples. 


\section{Results and Discussion}

\subsection{Properties of the SnS Films}

The SnS films are uniform, fairly porous and brown in colour. For simplification, here just show one typical Sample. EDS analysis indicates that the layer is nearly stoichiometric with $\mathrm{Sn}=48.31 \%$ and $\mathrm{S}=51.69 \%$ (seen in Figure 2). XRD patterns in Figure 3 reveal that the layer is polycrystalline SnS with a strong (111) preferred orientation. The film has resistivity of $423 \Omega \cdot \mathrm{cm}$ with a carrier density of $2.35 \times 10^{15} \mathrm{~cm}^{-3}$ and a Hall mobility of $6.29 \mathrm{~cm}^{2} \cdot \mathrm{v}^{-1} \cdot \mathrm{s}^{-1}$.

Figure 4 shows the optical transmittance of the SnS film in the wavelength range $400-1400 \mathrm{~nm}$. The sample shows a high absorption coefficient, with the $\alpha$ value higher than $10^{4} \mathrm{~cm}^{-1}$ in the photon energy range from 1.4 to $3.2 \mathrm{eV}$. The optical energy band gap was determined to be $1.37 \mathrm{eV}$, according to the $(\alpha \mathrm{h} v)^{2}$ versus $\mathrm{h} v$ plot (seen in Figure 5).

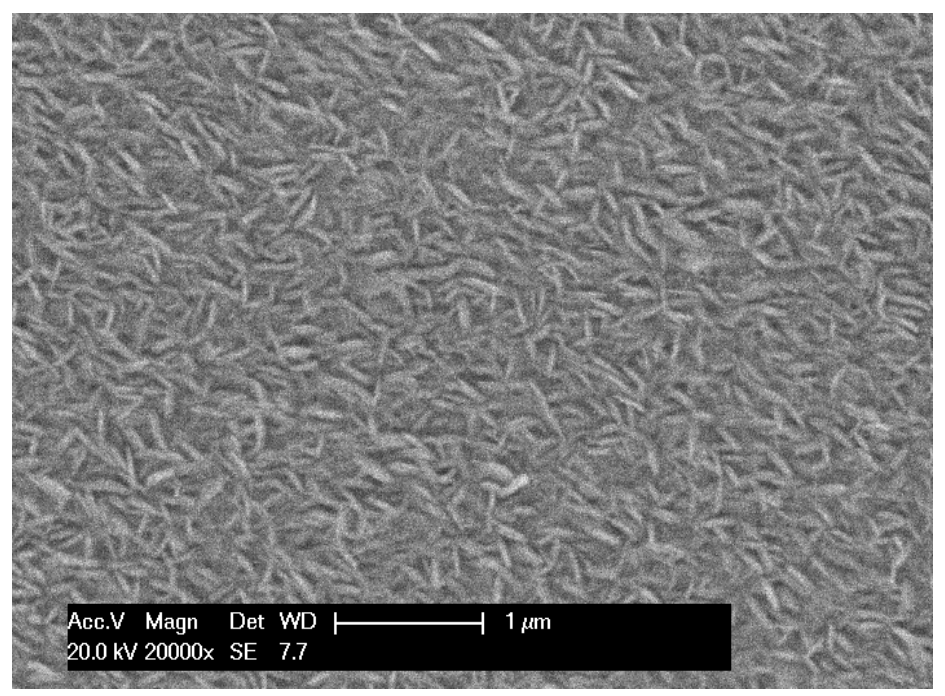

D:\EDAX32\EDS\USR $\backslash$ csy $\backslash 1031$ s1-1.spc

Label A:

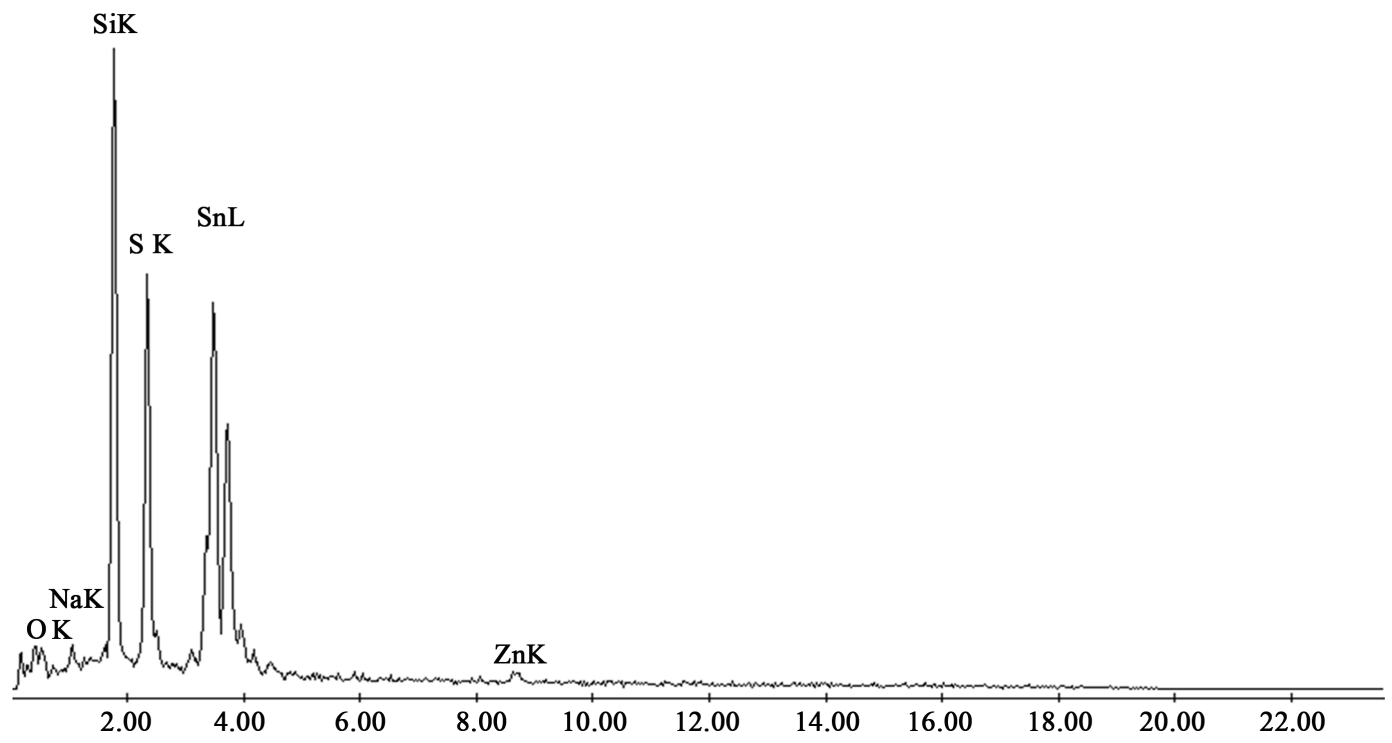

Figure 2. The SEM the SnS film. 


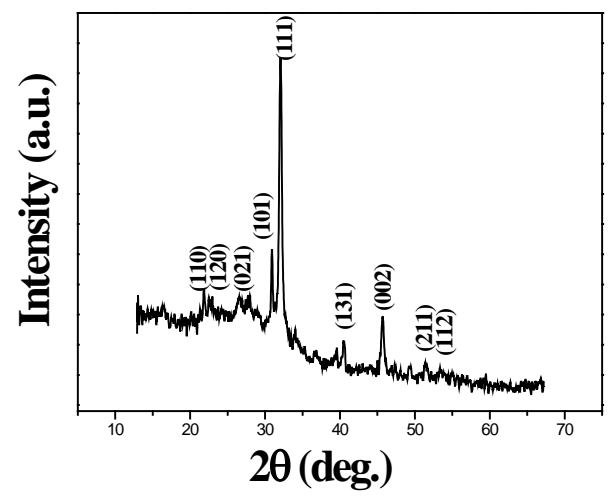

Figure 3. The XRD patterns of the SnS film.

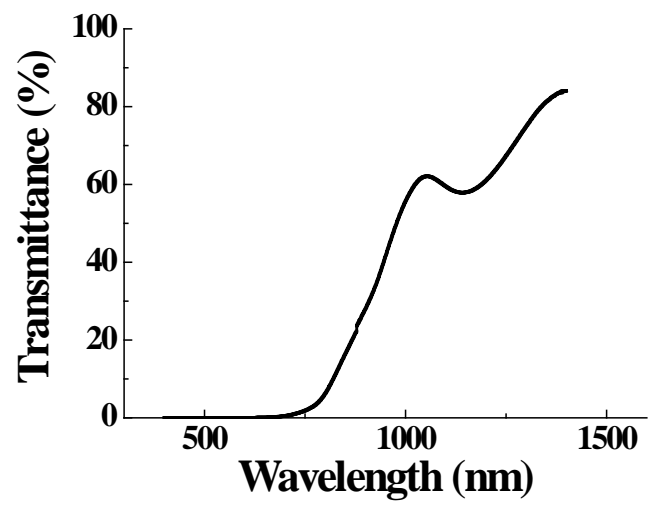

Figure 4. The optical transmittance of the SnS film.

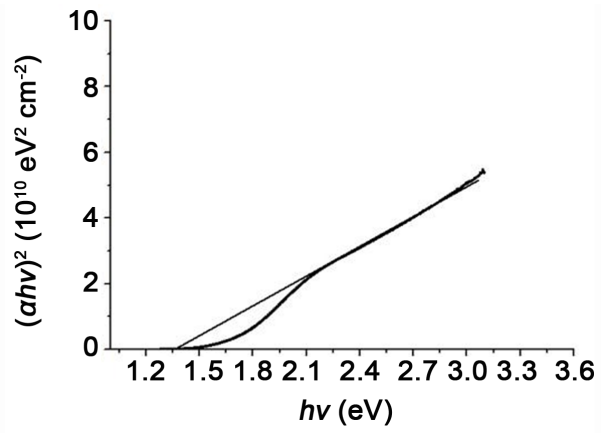

Figure 5. The band gap of the SnS film.

\subsection{Characterization of $\mathrm{SnS} / \mathrm{CdS}$ Heterojunctions}

SnS/CdS heterojunctions were prepared as the process described above. We discussed the relationship of the thickness and annealing temperature of the CdS buffer layers with the performance of SnS/CdS heterojunctions. We fabricated four solar cell samples with different CdS thicknesses ranging from 0 to approximate $80 \mathrm{~nm}$. In order to evaluate the solar cell performance, the SnS/CdS junctions with active areas of $0.8 \mathrm{~cm}^{2}$ were illuminated with a general lighting condition of $4.6 \mathrm{~mW} / \mathrm{cm}^{2}$. Figure 6 shows the I-V characterization of the devices with different thick CdS buffers under/without the illumination. Table 1 illustrates the parameters of the four solar cells with different CdS thicknesses. For different thicknesses, the fill factor value varied little, but the short circuit current and open circuit voltage changed much and the most appropriate thickness should be nearly $50 \mathrm{~nm}$, between $43 \mathrm{~nm}$ (Cell-2) and $65 \mathrm{~nm}$ (Cell-3). The proper thickness of the CdS buffer layer contributed to lower the reverse dark current and improve the open circuit voltage. The reverse dark currents of the devices were also connected with different thick CdS buffers (seen in Figure 7). The too thick CdS layer lowered the 


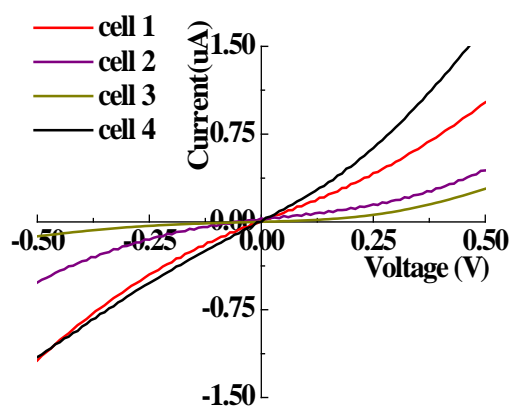

(a)

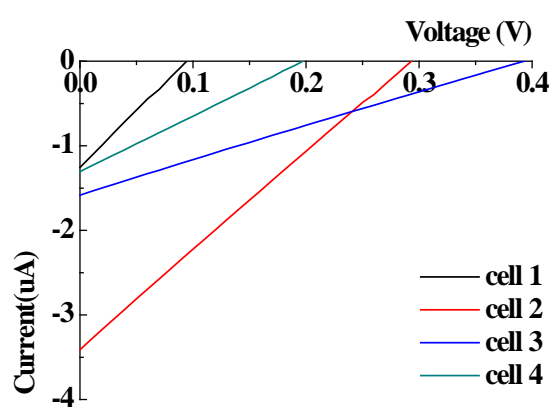

(b)

Figure 6. The I-V characterization of the devices with different thick CdS buffers. (a) Without lighting; (b) Under illumination $\left(4.6 \mathrm{~mW} / \mathrm{cm}^{2}\right)$.

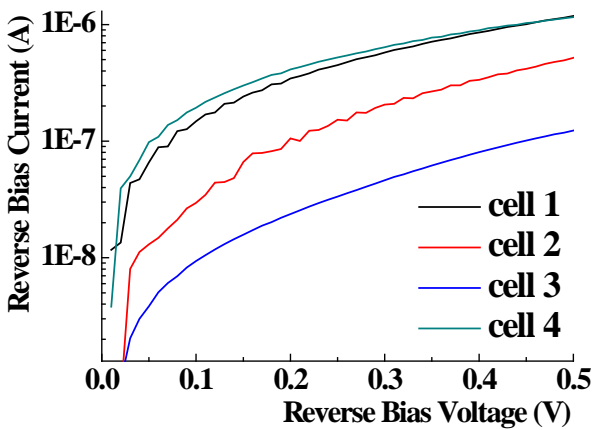

Figure 7. The reverse dark current of the devices with different thick CdS buffers (the values of current and voltage are actually negative).

Table 1. The parameters of four solar cells with different CdS thicknesses (under illuminated conditions $\left.\left(4.6 \mathrm{~mW} / \mathrm{cm}^{2}\right)\right)$.

\begin{tabular}{ccccc}
\hline Sample name & Cell- 1 & Cell-2 & Cell-3 & Cell-4 \\
\hline CdS thickness/nm & 0 & 43 & 65 & 86 \\
Cell's area/cm ${ }^{2}$ & 0.81 & 0.81 & 0.81 & 0.81 \\
$\mathrm{~V}_{\text {oc }} / \mathrm{mV}$ & 100 & 290 & 394 & 195 \\
$\mathrm{I}_{\mathrm{sc}} / \mathrm{uA}$ & 1.30 & 3.41 & 1.58 & 1.30 \\
$\mathrm{~V}_{\max } / \mathrm{mV}$ & 50 & 150 & 198 & 100 \\
$\mathrm{I}_{\max } / \mathrm{uA}$ & 0.60 & 1.64 & 0.77 & 0.65 \\
$\mathrm{P}_{\max } / \mathrm{mW}$ & $30 \times 10^{-6}$ & $246 \times 10^{-6}$ & $152 \times 10^{-6}$ & $65 \times 10^{-6}$ \\
Fill factor & 0.23 & 0.25 & 0.24 & 0.27 \\
\hline
\end{tabular}

electrical properties due to the relative high resistance.

According to the previous discussion, we fabricated another four samples with the optimum thickness (50 nm) of CdS buffer layers under different annealing temperatures. The parameters of four solar cells with different CdS annealing temperatures are shown in Table 2. Figure 8 shows the I-V characterization of the devices with different CdS annealing temperatures under/without the illumination. The samples annealed in vacuum at $350^{\circ} \mathrm{C}$ had the maximum of open circuit voltage and fill factor. The proper annealing temperature could decrease the defects of the CdS buffer layers and enhance the carrier transport properties. The higher annealing temperature could lead to the unacceptable mutual diffusions in the interfaces which lowered the electrical resistivity of the CdS buffer layer.

According to the most appropriate parameter of the thickness $(50 \mathrm{~nm})$ and annealing temperature $\left(350^{\circ} \mathrm{C}\right)$. 


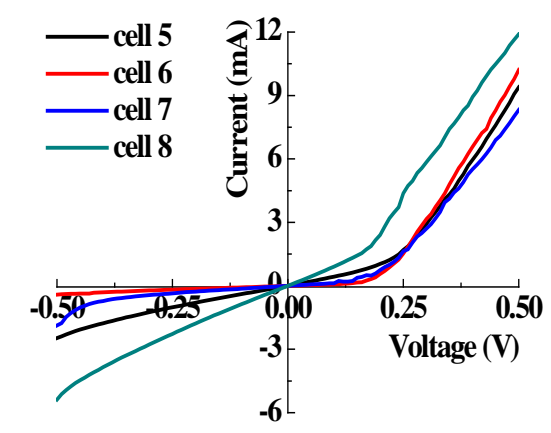

(a)

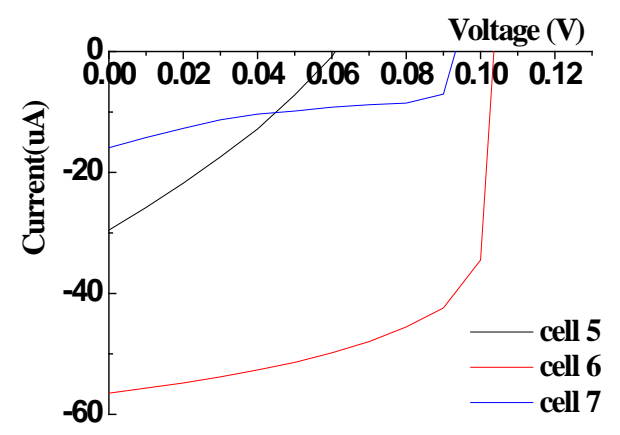

(b)

Figure 8. The I-V characteristics of the devices with different CdS annealing temperatures. (a) Without lighting; (b) Under illumination $\left(4.6 \mathrm{~mW} / \mathrm{cm}^{2}\right)$.

Table 2. The parameters of the four solar cells with different CdS annealing temperatures (under the illumination condition $\left(4.6 \mathrm{~mW} / \mathrm{cm}^{2}\right)$ ).

\begin{tabular}{ccccc}
\hline Sample name & Cell-5 & Cell-6 & Cell-7 & Cell-8 \\
\hline Annealing temperature $/{ }^{\circ} \mathrm{C}$ & 300 & 350 & 400 & 450 \\
Cell's area $/ \mathrm{cm}^{2}$ & 0.81 & 0.81 & 0.81 & 0.81 \\
CdS thickness & 55 & 58 & 52 & 60 \\
$\mathrm{~V}_{\text {oc }} / \mathrm{mV}$ & 61.2 & 102 & 90 & 0 \\
$\mathrm{I}_{\mathrm{sc}} / \mu \mathrm{A}$ & 29.5 & 56.5 & 15.9 & 0 \\
$\mathrm{~V}_{\max } / \mathrm{mV}$ & 32.6 & 98 & 86 & - \\
$\mathrm{I}_{\max } / \mu \mathrm{A}$ & 16.3 & 39.7 & 8.05 & - \\
$\mathrm{P}_{\max } / \mathrm{mW}$ & $0.53 \times 10^{-3}$ & $3.89 \times 10^{-3}$ & $0.69 \times 10^{-3}$ & - \\
Fill factor & 0.29 & 0.68 & 0.48 & -
\end{tabular}

The parameters of best device (sample cell-6) under AM 1.5 are shown in Table 3. The best device had a conversion efficiency of $0.0025 \%$ under AM 1.5. Figure 9 shows the I-V characteristics of sample cell-6 under AM 1.5. The $\mathrm{CdS} / \mathrm{SnS}$ heterojunction showed low $\mathrm{J}_{\mathrm{sc}}$ and conversion efficiency. The most significant problem is that the series resistance is too high in the device. The series resistance caused by the CdS buffer layer, decreased the photocurrent. The CdS/SnS junctions are considered to be of TYPE-II form of heterostructures and the conduction band offset (CBO) value is $-0.4 \mathrm{eV}$ [14]. This is largely due to the formation of a high barrier against photo-generated electrons (the desired optimal CBO in the range of $0-0.4 \mathrm{eV}$ ) [15]. In addition, the SnS thin films were lack of densification, and the defects decreased the open-circuit voltage. Further research should be made to improve the densification of the SnS thin films and decrease the density of defects and recombination. Atomic layer deposition may be a substitute way for fabricating uniform and pin-hole free SnS films. There are some other materials $(\mathrm{Zn}(\mathrm{O}, \mathrm{S})$, ZnMgO) could form the ideal type-I heterojunctions instead of CdS as buffer layers. They may have small positive CBO which is desirable to reduce interface recombination without any loss in photo-current collection.

\section{Conclusion}

The thermally evaporated SnS polycrystalline thin films were exclusively oriented along (111) direction. The I-V characteristic curves of SnS/CdS heterojunctions were related with the thickness and annealing temperature of CdS buffer layers. The optimum thickness and annealing temperature of CdS buffer layers were $50 \mathrm{~nm}$ and $350^{\circ} \mathrm{C}$, respectively. The efficiency was too low probably due to the excessive high series resistance. 


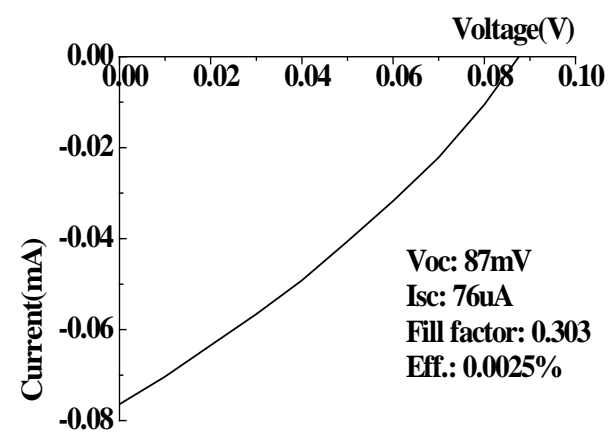

Figure 9. The I-V characteristics of sample cell-6 under AM 1.5.

Table 3. The parameters of sample cell-6 under AM 1.5.

$\begin{array}{cc}\mathrm{I}_{\mathrm{sc}} / \mathrm{mA} & 0.076 \\ \mathrm{~J}_{\mathrm{sc}} / \mathrm{mA} / \mathrm{cm}^{2} & 0.096 \\ \mathrm{~V}_{\mathrm{oc}} / \mathrm{V} & 0.087 \\ \mathrm{I}_{\max } / \mathrm{mA} & 0.041 \\ \mathrm{~V}_{\max } / \mathrm{V} & 0.05 \\ \mathrm{P}_{\max } / \mathrm{mW} & 0.002 \\ \text { Fill factor } & 0.303 \\ \text { Efficiency/\% } & 0.0025\end{array}$

\section{Acknowledgements}

This work was supported by the National Nature Science Foundation of China (61306120, 61340051) and Fujian Provincial Department of Science \& Technology, China (2012J01266).

\section{References}

[1] Valiukonis, G., Guseinova, D.A., Keivaitb, G. and Sileika, A. (1986) Optical Spectra and Energy Band Structure of Layer-Type $\mathrm{A}^{\mathrm{IV}} \mathrm{B}^{\mathrm{VI}}$ Compounds. Physica Status Solidi (b), 135, 299-307. http://dx.doi.org/10.1002/pssb.2221350130

[2] Engelken, R.D., McCloud, H.E., Lee, C., Slayton, M. and Ghoreishi, H. (1987) Low Temperature Chemical Precipitation and Vapor Deposition of $\mathrm{Sn}_{\mathrm{x}} \mathrm{S}$ Thin Films. Journal of Electrochemical Society, 134, 2696-2707. http://dx.doi.org/10.1149/1.2100274

[3] Ogah, O.E., Reddy, K.R., Zoppi, G., Zoppi, G., Forbes, I. and Miles, R.W. (2011) Annealing Studies and Electrical Properties of SnS-Based Solar Cells. Thin Solid Films, 519, 7425-7428. http://dx.doi.org/10.1016/j.tsf.2010.12.235

[4] Reddy, K.T.R., Reddy, N.K. and Miles, R.W. (2006) Photovoltaic Properties of SnS Based Solar Cells. Solar Energy Materials and Solar Cells, 90, 3041-3046. http://dx.doi.org/10.1016/j.solmat.2006.06.012

[5] Sugiyama, M., Miyauchi, K., Minemura, T., Ohtsuka, K., Noguchi, K. and Nakanishi, H. (2008) Preparation of SnS Films by Sulfurization of Sn Sheet. Japanese Journal of Applied Physics, 47, 4494. http://dx.doi.org/10.1143/JJAP.47.4494

[6] Pramanik, P., Basu, P.K. and Biswas, S. (1987) Preparation and Characterization of Chemically Deposited Tin(II) Sulphide Thin Films. Thin Solid Films, 150, 269-276. http://dx.doi.org/10.1016/0040-6090(87)90099-X

[7] Takeuchi, K., Ichimura, M., Arai, E. and Yamazaki, Y. (2003) SnS Thin Films Fabricated by Pulsed and Normal Electrochemical Deposition. Solar Energy Materials and Solar Cells, 75, 427-432. http://dx.doi.org/10.1016/S0927-0248(02)00192-7

[8] Noguchi, H., Setiyadi, A. and Nagamoto, T. (1994) Characterization of Vacuum-Evaporated Tin Sulfide Film for Solar Cell Materials. Solar Energy Materials and Solar Cells, 35, 325-331. http://dx.doi.org/10.1016/0927-0248(94)90158-9

[9] Miyawaki, T. and Ichimura, M. (2007) Fabrication of ZnS Thin Films by an Improved Photochemical Deposition Method and Application to ZnS/SnS Heterojunction Cells. Materials Letters, 61, 4683-4686. http://dx.doi.org/10.1016/j.matlet.2007.03.006 
[10] Hirano, T., Shimizu, T., Yoshida, K. and Sugiyama, M. (2011) Sulfurization Growth of SnS Films and Fabrication of $\mathrm{ZnO} / \mathrm{SnS}$ Heterojunction for Solar Cells. Proceedings of the 37th Photovoltaic Specialists Conference (PVSC) of the IEEE, Seattle, 19-24 June 2011, 1280-1282.

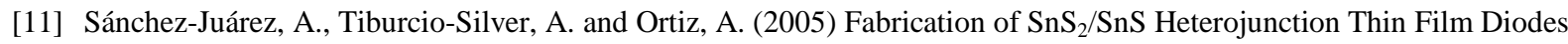
by Plasma-Enhanced Chemical Vapor Deposition. Thin Solid Films, 480-481, 452-456. http://dx.doi.org/10.1016/j.tsf.2004.11.012

[12] Sinsermsuksakul, P., Hartman, K., Kim, S.B., Heo, J., Sun, L.Z., Park, H.H., Chakraborty, R., Buonassisi, T. and Gordon, R.G. (2013) Enhancing the Efficiency of SnS Solar Cells Via Band-Offset Engineering with a Zinc Oxysulfide Buffer Layer. Applied Physics Letters, 102, Article ID: 053901. http://dx.doi.org/10.1063/1.4789855

[13] Shockley, W. and Queisser, H.J. (1961) Detailed Balance Limit of Efficiency of P-N Junction Solar Cells. Journal of Applied Physics, 32, 510-519. http://dx.doi.org/10.1063/1.1736034

[14] Sugiyamaa, M., Reddy, K.T.R., Revathi, N., Shimamoto, Y. and Murata, Y. (2011) Band Offset of SnS Solar Cell Structure Measured by X-Ray Photoelectron Spectroscopy. Thin Solid Films, 519, 7429-7431. http://dx.doi.org/10.1016/j.tsf.2010.12.133

[15] Minemoto, T., Matsui, T., Takakura, H., Hamakawa, Y., Negami, T., Hashimoto, Y., Uenoyama, T. and Kitagawa, M. (2001) Theoretical Analysis of the Effect of Conduction Band Offset of Window/CIS Layers on Performance of CIS Solar Cells Using Device Simulation. Solar Energy Materials and Solar Cells, 67, 83-88. http://dx.doi.org/10.1016/S0927-0248(00)00266-X 
Scientific Research Publishing (SCIRP) is one of the largest Open Access journal publishers. It is currently publishing more than 200 open access, online, peer-reviewed journals covering a wide range of academic disciplines. SCIRP serves the worldwide academic communities and contributes to the progress and application of science with its publication.

Other selected journals from SCIRP are listed as below. Submit your manuscript to us via either submit@scirp.org or Online Submission Portal.
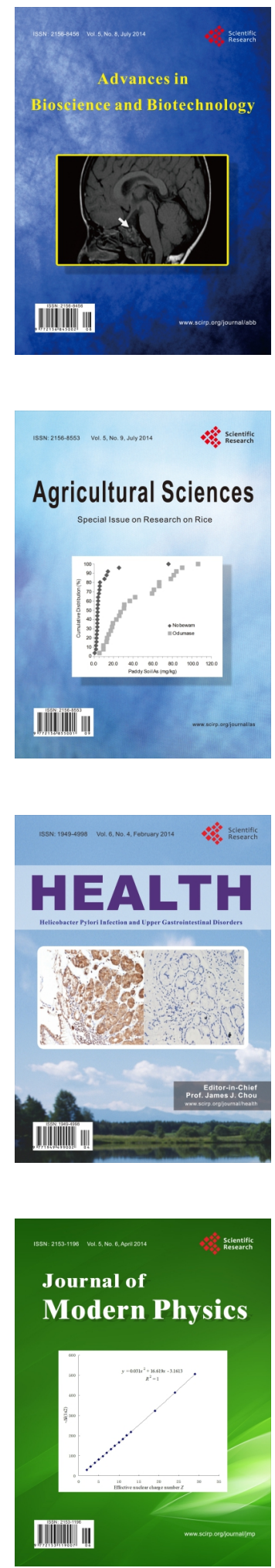
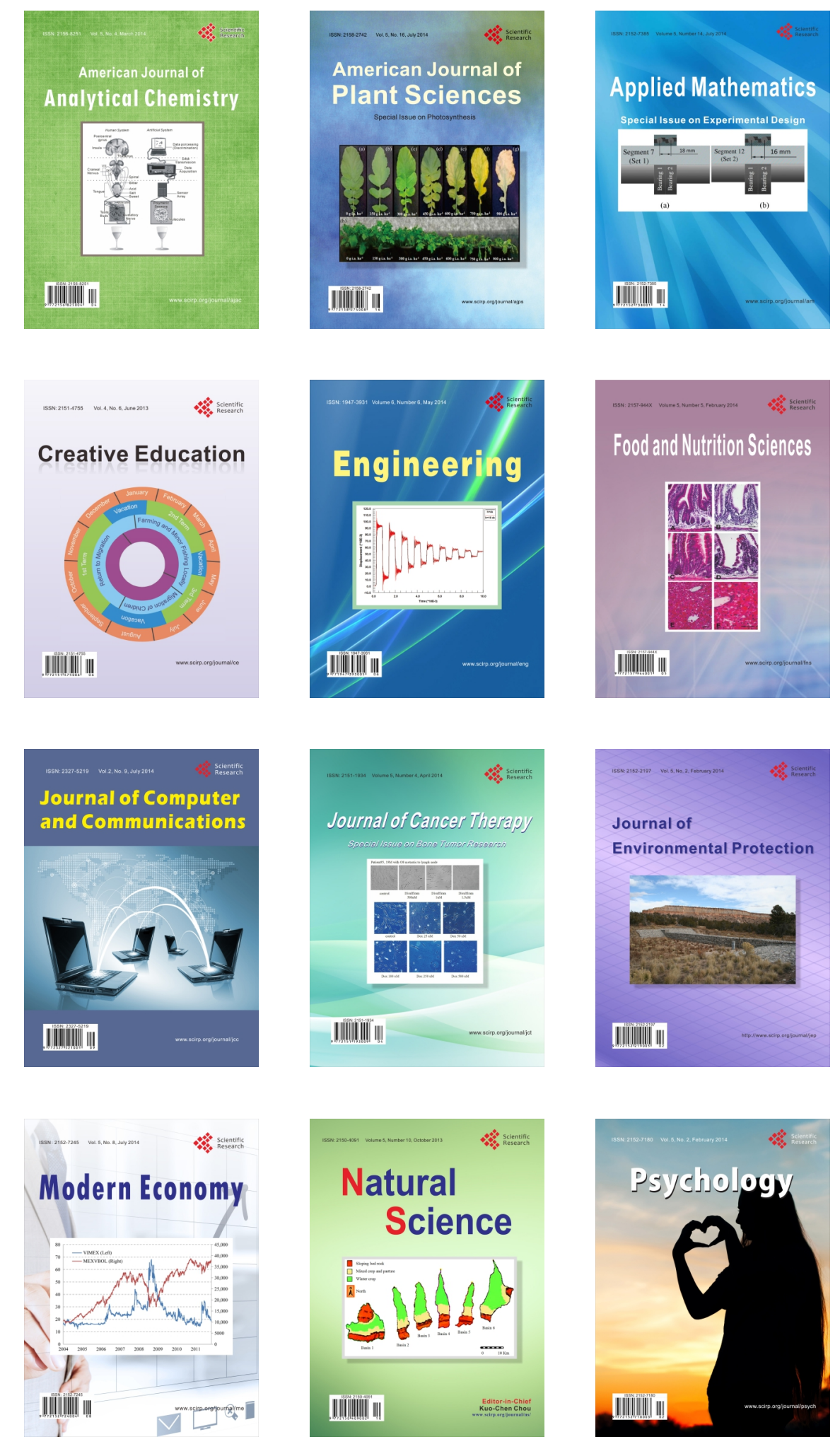